\title{
FORENSIC ACCOUNTING: CONCEPTS AND PROSPECTS OF APPLICATION IN UKRAINE
}

\author{
Dunaev M.S.,
}

Master Student of "Finance and Audit in Entrepreneurship"

Sumy State University

willis@i.ua

\section{Plikus I.J.,}

Ph.D., Associate Professor, Associate Professor of Financial Technologies and Entrepreneurship

Sumy State University

i.plikus@finance.sumdu.edu.ua

Otroshchenko L.S.,

Ph.D., Associate Professor of Foreign Languages,

Sumy State University

L.Otroshchenko@uabs.sumdu.edu.ua

Zhukova T. A.,

Senior lecturer of Financial Technologies and Entrepreneurship

Sumy State University

gtanya@buh.sumdu.edu.ua

The development of the economy, the consolidation of companies, and their activities lead to increased threats and risks associated with their operation. One of the biggest problems in this direction is the emergence of facts of corporate fraud; it is corporate crimes that pose a real and serious threat to the stability of any business. Fraud and theft of tangible property can lead to significant financial losses. Therefore, it is crucial to implement measures to prevent, detect and investigate financial crimes and respond immediately to illegal actions. The purpose of writing this article is to reveal the essential characteristics of the concept of "forensic accounting" to justify its use by businesses in Ukraine to prevent fraud. The article notes that after large-scale fraudulent schemes, corruption and financial fraud, the need for forensic accounting has increased both worldwide and in Ukraine, as evidenced by the interest of practitioners and the scientific community in the definitions of "forensic accounting" analyzed using Google Ngram Viewer (GNV) and provides economic crime statistics. An analysis of the existing definitions of "forensic accounting" and noted that some experts identify the concept of "forensic accounting" with "forensic audit". It is emphasized that forensic accounting is a set of control system measures, which, on the one hand, are aimed at preventing illegal actions committed by company officials, as well as to stop the abuse of office. On the other hand - they are aimed at investigating fraud, resulting from which the company's reputation was caused damage or significant financial losses. The comparative characteristics of audit and "forensic accounting" are given. It turns out that forensic accounting is an independent service in the system of expert services. The necessity of its development and application by business entities in Ukraine is substantiated. The main directions of forensic accounting are outlined, among which the prevention and investigation of fraud, support in court proceedings, corporate forecasting, IT investigations, compliance with anti-corruption legislation are highlighted.

Key words: forensic accounting, audit, internal control, financial crimes, accounting, corporate crimes.

DOI: $10.21272 / 1817-9215.2021 .3-11$

\section{INTRODUCTION}

The Association of Certified Fraud Examiners (ACFE) has determined that countries with economies in transition are more at risk of fraud in the business environment. The reasons are the underdeveloped internal control system and the lack of safety culture in enterprises as a whole. To detect fraud and the risks of its occurrence is not enough to use standard audit methods; one needs to resort to forensic accounting. Recently, foreign companies are actively using the services of "forensic accounting" to identify risks and negative consequences of criminal activity and ensure the company's effectiveness. Currently, Ukraine has not developed a corporate culture that would perceive forensic accounting as a necessary tool for supporting the company's activities. Existing western theory and practice and domestic experience in forensic accounting need detailed analysis in the face of intensive emergence of new fraudulent schemes, development of computer technology, changing legislation to find ways to improve forensic accounting for their application in the Ukrainian economic 
space. Therefore, there is a need for a comprehensive solution to the theory, methodology, organization, and implementation of forensic accounting.

\section{LITERATURE REVIEW}

Many foreign scientists and consulting companies deal with the formation and application of forensic accounting methodology. Among them are S.L. Skalaka, T.V. Golden, M.M. Clayton (PWC LLP practitioners), and scientists such as S. Freeman, C. Davis, G.A. Pascoe, E.V. Red, S.K. Dutta, L. Weaver, Farrell, and others. Ukrainian scientists are also studying this issue. So many foreign scientists and consulting companies deal with the formation and application of forensic accounting methodology. Among them are S.L. Skalaka, T.V. Golden, M.M. Clayton (PWC LLP practitioners), and scientists such as S. Freeman, C. Davis, G.A. Pascoe, E.V. Red, S.K. Dutta, L. Weaver, Farrell, and others. Ukrainian scientists are also studying this issue. So M.V. Dubinina, S.V. Syrtseva, Yankovskaya T.Y. [1] identified the main purpose of forensic accounting and the main characteristics that distinguish forensic accounting from audit and presented a conceptual model of forensic accounting as a method of investigating internal corporate cases of fraud. Chut M.A. [2] investigated the essence of forensic accounting procedure and the role of forensic accounting tools in cost-oriented enterprise management, analyzed the prerequisites for the need for forensic accounting in an industrial enterprise, identified the main elements of forensic accounting procedure Semenets A.O. [3] proposed to introduce the concept of "forensic audit" into accounting theory, investigated the purpose of the forensic audit, its subject, object, regulatory framework, frequency, and other essential characteristics. Melnychuk I. [4] considers the prevention of offenses in finance and proposes applying effective foreign practice, where forensic accounting services have become widespread. Scientific analysis of these studies has shown that the application of forensic accounting in Ukraine requires further research in both theoretical and practical areas.

\section{OBJECTIVES OF THE ARTICLE}

The purpose of the article is to reveal the essential characteristics of the concept of "forensic accounting" to justify its use by businesses in Ukraine to prevent fraud.

\section{RESULTS}

Corporate crime is a real and serious threat to the stability of any business. In addition, fraud and theft of tangible property can lead to significant financial losses. Therefore, it is essential to implement measures to prevent, detect and investigate financial crimes and respond immediately to illegal actions.

The development of the economy, the consolidation of companies, and their activities lead to increased threats and risks associated with their operation. One of the biggest problems in this direction is the emergence of facts of corporate fraud in various forms. Thus, according to the ACFE report, in 2020, the losses from corporate fraud with recorded cases in 125 countries amounted to more than 7 billion US dollars [5]. Among the main areas of fraud are misappropriation of assets $53 \%$, corruption $26 \%$, distortion of financial statements $11 \%$. Fig. 1 shows the level of economic crime in the world for 2010-2020.

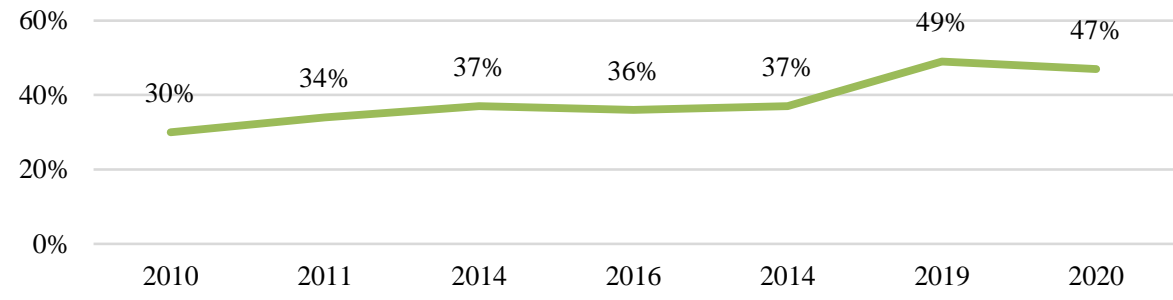

Figure 1-The level of economic crime in the world Source: compiled by the authors on the basis [6] 
The results of a review of various sources of information, including the World Economic Crimes Review for 2020 [7], conducted by PwC, show that almost every second company has faced various types of fraud related to corruption, seizure, and theft of assets, misrepresentation of financial statements, fictitious and intentional bankruptcy, tax crimes. In this regard, to ensure the economic security of the enterprise and to detect fraud in the enterprise, forensic accounting or forensic audit are used. The need for forensic accounting has grown, especially after large-scale schemes of fraud, corruption, and financial fraud in the economic crisis. This fact explains the interest of practitioners and the scientific community in the definitions of "forensic accounting", "forensic audit" (Fig. 2).

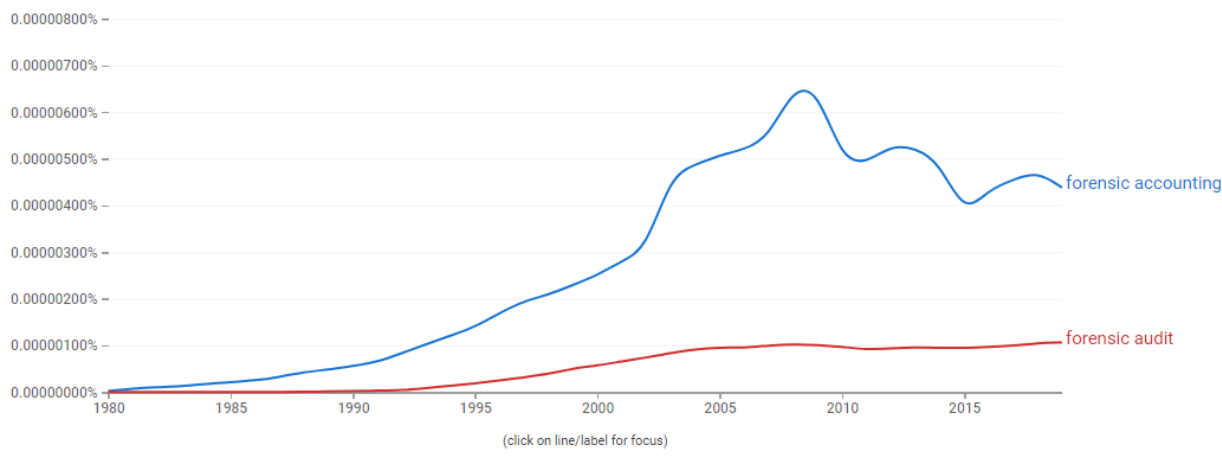

Figure 2 - Frequency of mentioning the words "forensic accounting", "forensic audit" in English literature publications, 1980-2019.

Source: compiled by the authors according to the data GNV

As we can see from (Fig. 2), the maximum frequency of mentioning the definition of "forensic accounting" falls on 2008 - the year of the global economic crisis of 2008-2010.

Note that the term "forensic accounting" was first used in a 1946 publication by Maurice Pelube, a former US law enforcement officer who founded a consulting company that provided corporate services, including forensic accounting [8]. However, today there are different definitions of this term, which are given in (table 1).

Table 1-Analysis of the concept of "forensic accounting", "forensic audit"

\begin{tabular}{|l|l|}
\hline \multicolumn{1}{|c|}{ Author } & $\begin{array}{l}\text { Definition of the term } \\
\text { Chirva E.V. [9] } \\
\text { independence, initiated by the owners or the board of directors of the company's } \\
\text { managers in case of suspicion of fraud" }\end{array}$ \\
\hline $\begin{array}{l}\text { Khorin O.M., Suyts } \\
\text { E.A. Kozeltseva }\end{array}$ & $\begin{array}{l}\text { "Forensic accounting - a set of independent services to assess the likelihood of fraud in } \\
\text { the financial sector, which are revealed to the owners or board of directors of companies } \\
\text { of various organizational and legal forms by auditing, consulting and other specialized } \\
\text { companies" }\end{array}$ \\
\hline Zlobova E.G. [11] & $\begin{array}{l}\text { "Forensic accounting - a set of actions aimed at identifying, legal analysis and search for } \\
\text { solutions to resolve situations where the parties in the framework of economic relations } \\
\text { there are differences on issues that are characterized by significant economic risks" }\end{array}$ \\
\hline $\begin{array}{l}\text { Rehman A., Hashim } \\
\text { F. [12] }\end{array}$ & $\begin{array}{l}\text { "Forensic accounting - a multidisciplinary service that considers civil, criminal, } \\
\text { economic, and financial claims (business or personal), based on theories, methods, and } \\
\text { procedures in the field of law, audit, accounting, finance, economics, psychology, } \\
\text { sociology, and criminology, in within established political, social parameters and clearly } \\
\text { defined legal jurisdictions." }\end{array}$ \\
\hline $\begin{array}{l}\text { Enofe A.O., } \\
\text { Omagbon P. [13] }\end{array}$ & $\begin{array}{l}\text { "Forensic accounting - generalizing activities combines accounting," investigative } \\
\text { "audit, forensics, forensic services and financial skills to detect, prevent fraud and reduce } \\
\text { their number" }\end{array}$ \\
\hline $\begin{array}{l}\text { Tyutchenko S.M. } \\
\text { [14] }\end{array}$ & $\begin{array}{l}\text { "Forensic accounting - service support of business, aimed at preventing the risks of } \\
\text { corporate fraud, detection of violations by employees and management of the company, } \\
\text { falsification of accounting and tax reporting, cases of theft or misuse of assets, } \\
\text { corruption, and abuse of power, as well as the assessment of and the development of an } \\
\text { acceptable mechanism for compensation and return of assets to owners." }\end{array}$ \\
\hline
\end{tabular}




\begin{tabular}{|l|l|}
\hline \multicolumn{1}{|c|}{ Author } & \multicolumn{1}{c|}{ Definition of the term } \\
\hline $\begin{array}{l}\text { Davis, Ch., Farrell } \\
\text { R., Ogilby, S. [15]. }\end{array}$ & $\begin{array}{l}\text { "Forensic accounting is a comprehensive study of financial and economic activities of } \\
\text { an economic entity, the purpose of which is to identify various facts of fraud, financial } \\
\text { fraud, other illegal actions, both by management and other employees, as well as others } \\
\text { third parties, in addition to proposing a system of measures to minimize them." }\end{array}$ \\
\hline $\begin{array}{l}\text { Albrecht, W. S., } \\
\text { Albrecht, C. C., } \\
\text { Albrecht, C. O. [16] }\end{array}$ & $\begin{array}{l}\text { "Forensic accounting - an effective tool, the use of which can significantly reduce the } \\
\text { risk of financial crimes" }\end{array}$ \\
\hline Solomina G.V. [17] & $\begin{array}{l}\text { "Forensic accounting is an effective tool aimed at researching all information flows } \\
\text { within the enterprise, as well as interaction with external parties, such as customers, } \\
\text { suppliers, regulated bodies, investors, and other stakeholders." }\end{array}$ \\
\hline $\begin{array}{l}\text { Dubinina M., } \\
\text { Ksonzhyk I., } \\
\text { Syrtseva S. [18] } \\
\text { Semenets A.O. [3] }\end{array}$ & $\begin{array}{l}\text { "Forensic audit - a continuous process that uses specific technology to detect suspicious } \\
\text { activities occurring in the company or its immediate business environment." }\end{array}$ \\
\hline
\end{tabular}

After analyzing the concept, we can state that:

- firstly, a review of the scientific literature has shown that at present, there is no precise and complete definition of "forensic accounting", so each author offers his definition, which takes into account certain aspects of the term;

- secondly, even though different scholars give their definitions of the term "forensic accounting", however, if we analyze and synthesize existing interpretations, we can say that forensic accounting - a set of analytical studies of financial and economic activities of the business entity, initiated by the owners or managers of the business entity, which is inspected under applicable law in order to identify the facts of financial fraud, fraud and other illegal actions of employees of the business entity and/or third parties related to the activities of the business entity;

- thirdly, the term "forensic accounting" also uses the term "forensic audit", which is usually considered research and evaluation of financial information of the entity conducting economic activities, the results of which can be used as evidence in court.

When considering forensic accounting, it is necessary to understand its differences from audit and internal control, which are shown in (table 2).

Table 2 - Comparative characteristics of internal control, audit and forensic accounting.

\begin{tabular}{|l|l|l|l|}
\hline \multicolumn{1}{|c|}{ Differences } & \multicolumn{1}{|c|}{ Internal control } & \multicolumn{1}{c|}{ Audit } \\
$\begin{array}{l}\text { The purpose } \\
\text { inspection } \\
\text { the }\end{array}$ & $\begin{array}{l}\text { Control over the economic } \\
\text { activity of enterprises in } \\
\text { terms of legality, } \\
\text { expediency, reliability }\end{array}$ & $\begin{array}{l}\text { Achieving confidence in } \\
\text { the accuracy of } \\
\text { enterprise reporting }\end{array}$ & $\begin{array}{l}\text { Analysis of the possibility of } \\
\text { fraud risk or its detection }\end{array}$ \\
\hline Users & $\begin{array}{l}\text { Aimed at senior and middle } \\
\text { managers }\end{array}$ & $\begin{array}{l}\text { Aimed primarily at users } \\
\text { of financial statements }\end{array}$ & $\begin{array}{l}\text { Aimed at users who want to find } \\
\text { evidence of fraud and determine } \\
\text { the risk of its occurrence }\end{array}$ \\
\hline $\begin{array}{l}\text { Methods of } \\
\text { conducting }\end{array}$ & $\begin{array}{l}\text { Analysis of accounting, } \\
\text { financial reporting, control } \\
\text { over the state of assets, the } \\
\text { provision of working capital } \\
\text { of the enterprise }\end{array}$ & $\begin{array}{l}\text { Observation, report on } \\
\text { accounting transactions, } \\
\text { confirming the correct } \\
\text { content of financial } \\
\text { statements }\end{array}$ & $\begin{array}{l}\text { Detailed review of both financial } \\
\text { and non-financial information, } \\
\text { organization and conduct of } \\
\text { interviews, implementation of } \\
\text { third-party requests }\end{array}$ \\
\hline $\begin{array}{l}\text { Results of } \\
\text { the } \\
\text { inspection }\end{array}$ & $\begin{array}{l}\text { Providing information for } \\
\text { management decisions }\end{array}$ & $\begin{array}{l}\text { Increase of confidence in } \\
\text { reported financial } \\
\text { information }\end{array}$ & $\begin{array}{l}\text { Report on suspicions of fraud, } \\
\text { persons accused of it and the facts } \\
\text { of the accusation }\end{array}$ \\
\hline
\end{tabular}

Forensic accounting is carried out in the following stages: preliminary, analytical, evaluation and final.

The preliminary stage is the study by specialists of the history of the company's operation, scale, structure, and branch of operation before agreeing on forensic accounting. The inspection scheme, conditions, terms of the inspection, payment for the service are discussed. 
Analytical stage - collection and analysis of information: interviews with employees of the customer, interviewed managers and employees of the enterprise, analysis of policies and regulations of the entity, research of major business processes and internal control systems.

The evaluation phase identifies and analyzes vulnerabilities in the internal control system: risk assessment, control of activities, information, communication, and monitoring. Then the presence or absence of fraud of employees of the organization is established, and the risky directions of activity of the business entity where the financial crime can arise are specified.

The final stage - providing a list of reporting documents: report on the interview: the results of the analysis of databases, analytical procedures: a conclusion on the facts of fraud with evidence; a list of shortcomings of internal control of processes and results and possible scenarios and schemes of fraud; recommendations on the risk management system.

The process of forensic accounting includes several areas of financial investigation, which are formed and reflected in (Fig. 3).

DIRECTIONS OF SERVICES "FORENSIC ACCOUNTING"

Financial investigations

Establishing a certain fact of fraud; determining the causes; investigation of possible types of fraud in the organization

IT-investigation

Collection of electronic evidence; checking and analyzing databases for signs of fraud; review of electronic correspondence; extraction and processing of information on electronic media

Detection of intentional bankruptcy

Analysis of documents to identify transactions that raise doubts and suspicions assessment of the accuracy of information provided by the borrower; analysis of the actual use of loans received; study of the scheme of withdrawal of funds from the oroanization ahroad

Expertise

Preparation of information for court proceedings; assistance in court proceedings;

onndurtinc avtraindicial avamination

Corporate intelligence

Verification of reliability and affiliation; analysis of data on the reputation of partner organizations

Fraud risk and compliance

Assessment and improvement of the existing risk management system at the enterbrise: development of risk management measures

Figure 3 - The main directions of forensics

Source: grouped by authors based on [21, 22, 23, 24] 
Also, experts cite the following areas of forensic accounting:

1. Prevention and investigation of financial fraud. Corporate fraud is a real and severe threat to any business, can cause significant financial losses, and damage the company's reputation. Therefore, it is crucial to take appropriate measures to prevent and timely investigate financial crimes. Forensic accounting makes it possible to implement and timely identify existing risks of fraud and develop measures to eliminate identified shortcomings in order to reduce the risks of fraud, development, and implementation of control procedures aimed at reducing risks to track and prevent fraud in the company; checking business partners and monitoring the absence of conflicts of interest; building an effective function of investigating fraud; development of an action plan in case of detection of fraud.

2. Corporate forecasting - a specialized area of forensic accounting, in which a separate team of specialists regularly conducts comprehensive research on the business reputation and integrity of the company's counterparties.

3. IT-technologies of investigations provide for research and analytical activities using the latest technologies, collection of electronic evidence; search, analysis and storage of electronic data, recovery of deleted and decryption of protected information.

4. Assistance in litigation. The development of financial services for producers and suppliers who conduct business on a deferred payment basis is inevitably accompanied by litigation. Forensic accounting analyzes the entire financial picture of disputes, reducing uncertainty and increasing confidence resulting from an instigated dispute. Forensic accounting allows to resolve the situation through pre-trial investigation, increase business efficiency, ensure investments, and gather evidence for litigation. To do this, one should use special methods of collecting information, including:

- Various forms of complex inspections of all divisions of the enterprise;

- Express diagnostics of business for fraud within the enterprise;

- Investigation based on open sources (OSINT concept) [25]

- Obtaining information through external and internal agents.

5. Compliance with current legislation includes conducting an independent assessment of the risks associated with possible non-compliance with the country's laws, preparing practical recommendations for optimizing policies and procedures, and assisting in their implementation. Forensic accounting is also used to investigate violations of anti-corruption legislation and international treaties, such as avoiding double taxation. Thus, forensic accounting services are used to track the presence of illegal income of subsidiaries located abroad, including in offshore areas, analysis of contractual obligations, or the detection of significant accounts payable.

The development of forensic accounting and its allocation as an independent service has led to the emergence of international organizations that perform a regulatory function, in particular: Association of Certified Fraud Examiners (ACFE), Association of Certified Financial Crime Specialists (ACFCS), Association of Certified Anti-Money Laundering Specialists (ACAMS), Alliance IFA Forensic (IFA, Alliance), American College of Forensic Examiners Institute (ACFEI), Association of Certified Forensic Investigators (ACFI). The spread of forensic accounting services in corporations abroad, based on research conducted by foreign experts [26], indicates that the training of specialists in this field is carried out at the level of educational institutions when students study special courses, which further allow them to obtain a professional certificate, which confirms the level of their professional competencies. For Ukraine, this area of study is also promising.

\section{CONCLUSIONS}

Every year, the number of economic crimes is growing worldwide and in Ukraine, which is the reason for the need for a new service that would be aimed at detecting and preventing fraud. Such a service is forensic accounting - a set of control system measures, which, on the one hand, are aimed at preventing illegal actions committed by company officials, as well as to stop abuse of office, and on the other hand - they are aimed at investigating fraud, as a result of which the company's reputation was caused damage or significant financial losses. 
Areas of further research should be the development of a holistic mechanism for the functioning of the financial investigation service in Ukraine, which will ensure complete detection of the facts of financial crimes and punishment of violators and prevent their recurrence in the future.

\section{АНОТАЦЯ}

Дунаєв М.С., Плікус І.Й., Отрощенко Л.С., Жукова Т.А. Forensic accounting: поняття та перспективи застосування в Україні.

Розвиток економіки, укрупнення компаній, масштабів їх діяльності призводять до збільшення загроз $і$ ризиків пов'язаних з їх функціонуванням. Однією з найбільших проблем у цььому напрямку є поява фактів корпоративного иахрайства, саме корпоративні злочини являють собою реальну $i$ серйозну загрозу стабільності будь-якого бізнесу. Шахрайство та розкрадання матеріальної власності може призвести до суттєвих фінансових збитків. Тому надзвичайно важливим є впровадження заходів для запобігання, виявлення та розслідування фінансових злочинів $і$ негайного реагування на протиправні дії. Метою написання статті $\epsilon$ розкриття сутнісних характеристик поняття "forensic accounting" для обтрунтування його застосування суб'єктами господарювання в Украӥні з метою попередження шахрайства. У статті зазначено, що після масштабних шахрайських схем, корупції і фінансових махінацій зросла необхідність застосування forensic accounting як в усьому світі, так і Україні й про це свідчить інтерес практикуючих фахівців та наукової спільноти до дефініцій "forensic aсcounting» який проаналізовано з використанням інструменту Google Ngram Viewer (GNV) та надається статистика економічних злочинів. Проведено аналіз існуючих визначень дефініції «forensic accounting» та зазначено, щзо деякі фахівці ототожнюють поняття «forensic accounting» 3 "forensic audit». Наголошено, щзо forensic accounting - комплекс заходів системи контролю, які, з одного боку, спрямовані на запобігання вчинення протиправних дій, щзо здійснюються посадовими особами компанії, а також на припинення зловживання службовим становищем, а з іншого, - вони спрямовані на розслідування фактів шахрайства, внаслідок яких репутації компанії було завдано збитків або істотних фінансових втрат. Наводиться порівняльна характеристика аудиту та «forensic accounting». Доводиться, щз forensic accounting є самостійною послугою в системі експертних послуг. Обгрунтовано необхідність його розвитку $i$ застосування суб'єктами господарювання в Україні. Окреслено основні напрями forensic accounting, серед яких виділені запобігання та розслідування фактів шахрайства, супровід в судових провадження, корпоративні прогнозування, IT-технології розслідувань, дотримання вимог антикорупційного законодавства.

Ключові слова: forensic aсcounting, аудит, внутрішній контроль, фінансові злочини, бухгалтерський облік, корпоративні злочини.

\section{REFERENCES}

1. Dubinina M.V., Syrtseva S.V., Yankovskaya T.Yu. (2019). Forensic as a method of investigating internal corporate fraud cases. Market Infrastructure, Vol. 38, 377-383

2. Chut M.A. (2020). Using forensic tools to ensure the maximum value of the manufacturing plant. Economy and State, № 12, 145-152

3. Semenets A.A. (2019). Forensic Audit as an Efficient Means of Crisis Management of Trading Activities. Business Inform, 4, 280-287. URL: https://doi.org/10.32983/2222-4459-2019-4-280-287

4. Melnichuk I. (2021). Forensics as a form of prevention of financial offenses. Economy and Society, Vol. 25.

5. Report to the nations 2020. Global study on occupational fraud and abuse. URL: https://acfepublic.s3-uswest-2.amazonaws.com/2020-Report-to-the-Nations.pdf

6. PriceWaterhouseCoopers URL: https://www.pwc.ru/

7.PwC Global Survey Respondents: Economic Crime Damage to Business

URL: https://www.pwc.ru/ru/press-center/2020/ushcherb-biznesu-ot-ekonomicheskikh-prestupleniy.htm

8. Nunn L., McGuire B.L., Whitcomb C., Jost E. (2006). Forensic Accountants: Financial Investigators Journal of Business \& Economics Research, Vol. 4, № 2. URL: https://core.ac.uk/download/pdf/268111952.pdf

9. Chirva E.V. (2016). Forensic service as an effective tool to prevent and reduce fraud risks. Actual problems of modern economic science, 309

10. Suyts V.P., Khorin A.N., Kozeltseva E.A. (2015) Forensic service: professional training and regulation in foreign countries. Audit and financial analysis, 2, 194-200. URL: https://auditfin.com/fin/2015/2/fin_2015_21_rus_04_09.pdf

11. Zlobova E.G., Shvyreva O.I. (2016). Forensic technology: analytical procedures for checking income and expenditures. Problemy i perspektivy razvitiya ekonomicheskogo kontrolya i audita v Rossii, p. 62.

12. Rehman A., Hashim F. (2017). Forensic Accounting on Corporate Governance Maturity mediated by Internal Audit: A Conceptual Overview. Conference: 1st Economics and Business International Conference 2017 (EBIC 2017). DOI:10.2991/ebic-17.2018.26. URL: https://www.researchgate.net/publication/323712993_Forensic_Accounting_on_Corporate_Governance_Maturity mediated_by_Internal_Audit_A_Conceptual_Overview

13. Enofe A., Omagbon P., Ehigiator F.I. (2015). Forensic audit and corporate fraud. IIARD International

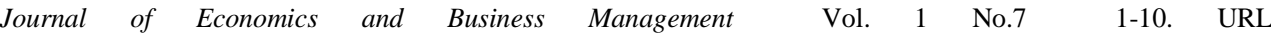
https://www.researchgate.net/publication/299843206_FORENSIC_AUDIT_AND_CORPORATE_FRAUD 
14. Tyutchenko S.M. (2021). Functions of forensics as a tool to prevent corporate fraud and increase the economic security of enterprises. Efficient economy, p.5. URL: http://www.economy.nayka.com.ua/pdf/5_2021/101.pdf

15. Davis, Ch., Farrell R., Ogilby, $\bar{S}$. Characteristics and skills of the forensic accountant. The American institute of certified public accountants. URL: http://thefraudgroupllc.com/tools/library/documents/forensic.pdf

16. Albrecht, W. S., Albrecht, C. C., Albrecht, Ch. O. (2012). Forensic accounting. Andover, Hampshire: South-Western cengage learning, 2012. $667 \mathrm{p}$

17. Solomina G.V. (2018). Forensic - a tool for financial investigation of the enterprise. Scientific Bulletin of Mukachevo State University. № 2, pp.144-149.

18. Dubinina M., Ksonzhyk I., Syrtseva S. (2018). Forensic accounting: the essence and prospects of development in Ukraine. Baltic Journal of Economic Studies. Vol. 4, № 1. pp. 131-138.

19. Godovana L.G., Butinets T.A. (2015). Internal control and internal audit, similarities and differences. URL: http://eztuir.ztu.edu.ua/jspui/bitstream/123456789/139/1/21.pdf

20. The difference between auditors and forensic accountants. (2020). URL: https://uncoverfraud.com/thedifference-between-auditors-and-forensic-accountants

21. Brown R., Gillespie S. (2015). Overseas financial investigation of organized crime: Examining the barriers to effective implementation. Journal of Money Laundering Control. № 18 (3), pp. 371-381.

22. Darrat A.F. et al. (2016). Corporate governance and bankruptcy risk. Journal of Accounting, Auditing \& Finance. № 31 (2), pp. 163-202.

23. Branson L., Nation F., Stephens J. (2016). Time on task: does it matter in governmental compliance auditing. International Journal of Business, Accounting, \& Finance. № 10 (2). pp. 45-52.

24. Wutiphan J., Ussahawanitichakit P., Janjarasjit S. (2015). Strategic audit expertise orientation and audit success: a conceptual framework. Allied Academies International Conference. Academy of Accounting and Financial Studies. Proceedings. Jordan Whitney Enterprises, № 20 (2), 55 p

25. OSINT Framework. URL: https://www.sentinelone.com/blog/what-is-osint-how-is-it-used/

26. McMullen D.A., Sanchez M.H. (2010). A Preliminary Investigation of the Necessary Skills, EducationRequirements, and Training Requirements for Forensic Accountants. Journal of Forensic \& Investigative Accounting Vol. 2, Issue 2, 30-48. URL: http://web.nacva.com/JFIA/Issues/JFIA-2010-2_2.pdf 